\title{
Upper Silurian and Lower Devonian conodonts from the Monte Cocco II Section (Carnic Alps, Italy)
}

\author{
MARIA G. CORRIGA \& CARLO CORRADINI
}

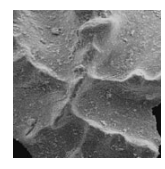

\begin{abstract}
The upper Silurian-Lower Devonian Monte Cocco II section, located in the eastern part of the Carnic Alps, yielded abundant conodonts from five conodont biozones (snajdri, crispa, eosteinhornensis s.l., detortus and woschmidti). The eosteinhornensis s.l. interval Zone is introduced here to replace the "Oz. remscheidensis i.Z." of Corradini \& Serpagli (1999). The Silurian/Devonian boundary is located in the upper part of the section; problems related to the accurate location of the Silurian/Devonian boundary on the basis of conodonts are discussed. A new taxon of the genus Pelekysgnathus is described, but left in open nomenclature. A few taxonomic notes on other selected taxa are also presented. - Key words: Silurian/Devonian boundary, conodonts, biostratigraphy, taxonomy, Carnic Alps.
\end{abstract}

Corriga, M.G. \& CoRradinI, C. 2009. Upper Silurian and Lower Devonian conodonts from the Monte Cocco II Section (Carnic Alps, Italy). Bulletin of Geosciences 84(1), 155-168 (6 figures, 1 table). Czech Geological Survey, Prague. ISSN 1214-1119. Manuscript received November 24, 2008; accepted in revised form March 10, 2009; published online March 23, 2009; issued March 31, 2009.

Maria G. Corriga, Dipartimento di Scienze della Terra, Università di Cagliari, via Trentino 51, I-09127 Cagliari; maria.corriga@ unica.it • Carlo Corradini (corresponding author), Dipartimento di Scienze della Terra, Università di Cagliari, via Trentino 51, I-09127 Cagliari; corradin@unica.it

This paper is a contribution to a cooperative research project on the Silurian of the Carnic Alps arranged between several Italian universities (Cagliari, Modena and Reggio Emilia, Pescara) and institutions (Museo Friulano di Storia Naturale). Research includes geological mapping, palaeontology, stratigraphy and depositional history of Silurian rocks, with special regard to carbonatic facies, in several sectors of the Carnic Chain. The ultimate goal of the project is to provide a reconstruction of the paleoenvironmental and paleogeographical evolution of the Carnic Basin during Silurian times.

Silurian and Lower Devonian sediments in the Carnic Alps are represented either by cephalopod limestone ("Orthoceras limestone") or black shales. They crop out discontinuously in many localities in the region between Wolayer Lake and the Uqua Valley. The central and western sectors of the chain (Wolayer Lake, Passo di Monte Croce Carnico/Plöckenpaß and Oberbuchach areas) have been investigated and described in great detail by several authors, while only a few papers deal with Silurian topics from other areas of the Carnic Alps.

Monte Cocco is located in the eastern part of the Carnic Alps. Here Silurian and Lower Devonian sediments are mainly represented by "Orthoceras limestones", but locating sections spanning the Silurian/Devonian boundary is difficult, because of either tectonic disturbance or the Quaternary cover. The "Monte Cocco II" section is the only section in the area where the Silurian/Devonian boundary is exposed and yields a quite rich conodont fauna.

Revision of conodont stratigraphy across the S/D boundary has been provided recently by Carls et al. (2007). In addition to defining some new taxa, the authors highlighted and discussed in detail problems with the various biozonation schemes proposed for the Prrídolí time. Although their arguments are valid, unfortunately they do not provide any new scheme to substitute for those criticized. Also, the recognition of the Silurian/Devonian boundary on the basis of conodonts is still a problem; the boundary is defined by the first occurrence of the graptolite species Mongraptus uniformis with no conodont taxa appearing at exactly the same time

\section{Previous work in the area}

The Monte Cocco area has long been known to geologists because of the abundance of fossils (Frech 1888) and the presence of iron and manganese which led to mining activity (Feruglio 1970, Zucchini 1998). However, geologic and stratigraphic studies of this area are quite old, with the exceptions of Herzog (1988), which has a structural approach only and Corradini et al. (2003), which is a preliminary report on the Silurian Cephalopod limestones. It should be pointed out that this locality is referred to by its Austrian name, "Kokberg", in old papers and by German speaking 


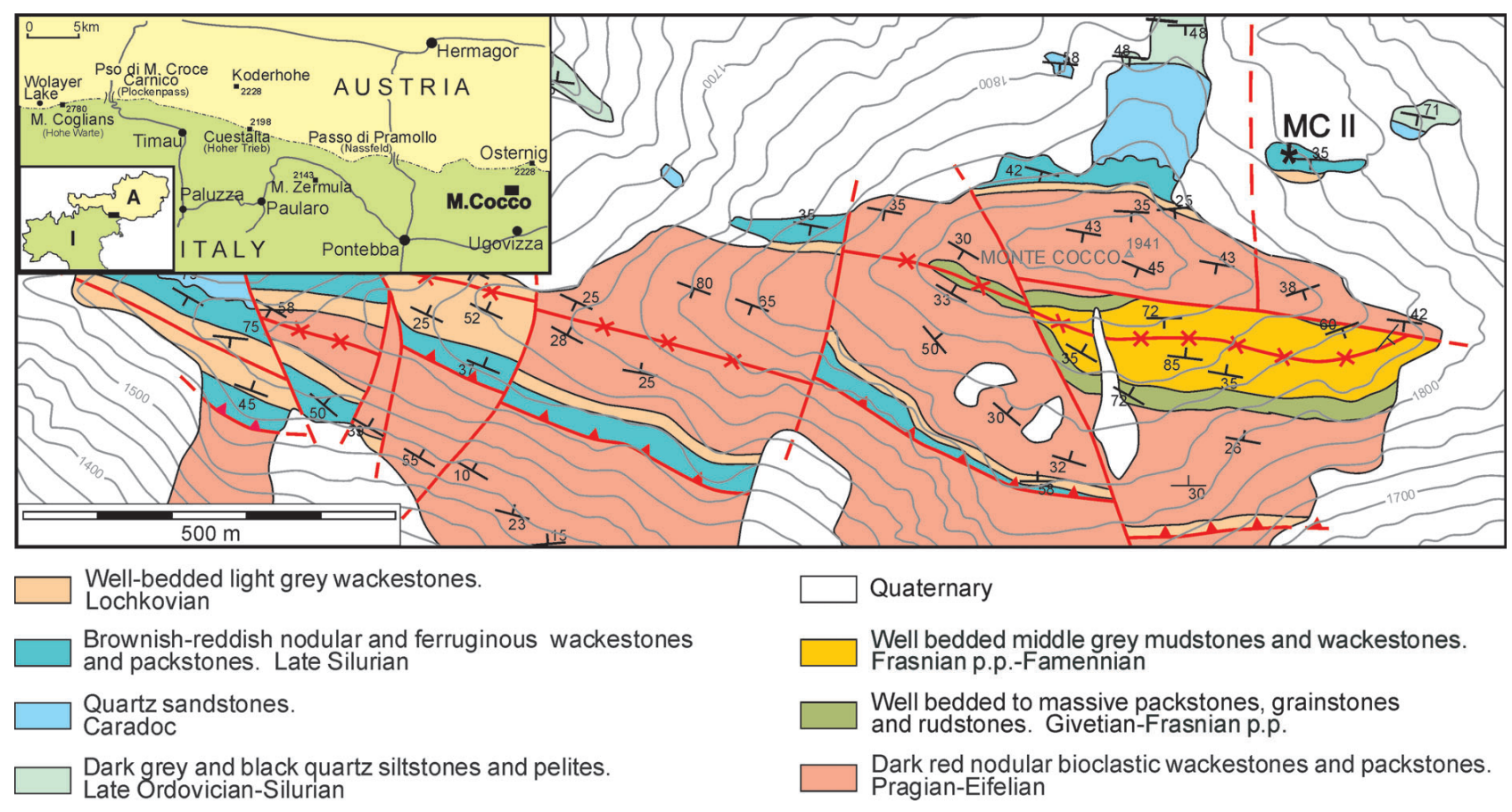

Figure 1. Geological map of the Monte Cocco area (modified after Corradini et al. 2003), with the location of the Monte Cocco II (MC II) section.

scientists; Monte Cocco was annexed to Italy only at the end of World War I.

The Silurian rocks of Monte Cocco are highly fossiliferous, and many papers deal with the taxonomy of selected groups, especially the nautiloid cephalopods (for a list of papers see Corradini et al. 2003). A few bivalves have been listed by Kř́ž (1999) in his monograph on Silurian bivalves from the Carnic Alps. Manzoni (1965) and Herzog (1988) looked at the occurrence of conodonts and listed some taxa of Wenlock and Ludlow age, and Corradini et al. (2003) published a preliminary paper on conodont stratigraphy of Ludlow-Př́ídolí age, in which some macrofossils were also illustrated.

\section{Geological setting}

Sediments of Late Ordovician to Late Devonian age are exposed in the Monte Cocco area (Fig. 1). The basal part of the succession consists of dark grey to greenish pelites and siltstones, grading to light grey sandstones (Uqua Fm.) of Katian-Hirnantian age. Locally, a massive $10 \mathrm{~m}$ thick crinoidal limestone of presumably Hirnantian age occurs.

The Silurian rocks are relatively widespread and mainly represented by a cephalopod limestone in Wolayer facies (Corradini et al. 2003), which disconformably overlies the Ordovician sediments. The lower part of the Silurian sequences (up to the uppermost Gorstian) is represented by dark brown to black wackestone to packstone (Kok Fm.), cropping out mainly on the western flank of
Monte Cocco. The upper part of the succession consists of about twenty meters of wackestones and packstones ("Alticola Lms") that are well stratified in beds $10-50 \mathrm{~cm}$ thick. The brownish-reddish colour of these beds frequently weathers to dark red due to the abundance of iron minerals present, and progressively grades to light grey across the Silurian/Devonian boundary. Fossils are common, mainly nautiloid cephalopods, trilobites and bivalves (Corradini et al. 2003). The inference of pelagic and hemipelagic deposition for these beds is supported by the lack of structures documenting traction currents.

The "Orthoceras limestones" are conformably overlain by about $10 \mathrm{~m}$ of well-bedded light grey Lochkovian cephalopod wackestones and packstones (Rauchkofel Fm. and Boden Lms), which represent a marked shallowing of the sea level. The depositional processes are still pelagic and hemipelagic, but a few tempestites reflecting major storm events are documented.

The succession continues with dark red nodular limestones (Findenig Fm.) of Pragian to Givetian age and bioclastic grainstones and rudstones (Eifelian-Givetian). The youngest pre-Variscan sediments in the Monte Cocco area are represented by pelagic limestones ("Clymeniae Lms") of Upper Devonian age.

\section{The Monte Cocco II (MC II) section}

The Monte Cocco II section is located on the northern flank of Monte Cocco at GPS coordinates N 46 33'03", E 

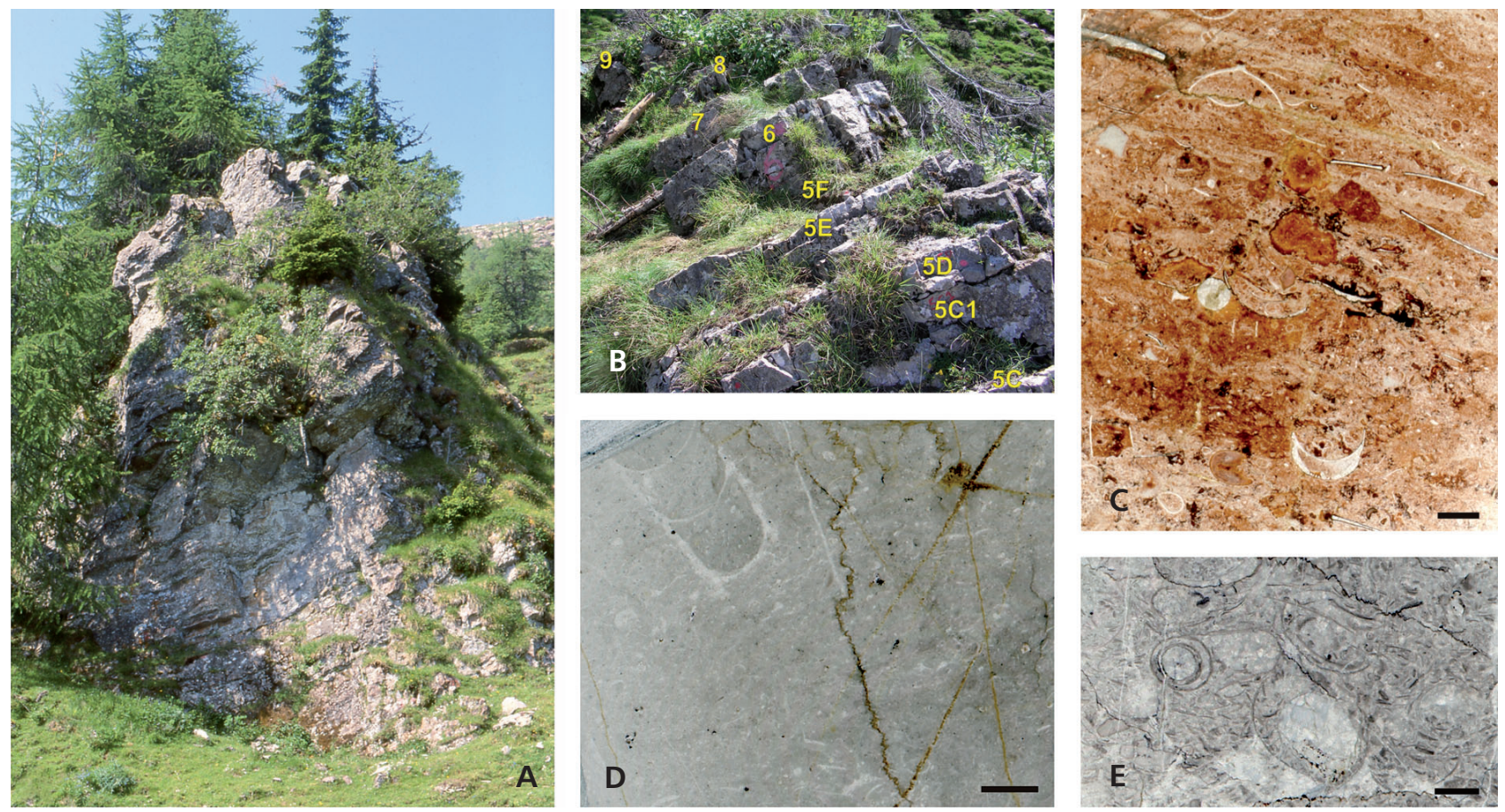

Figure 2. A - panoramic view of the Monte Cocco II section. $\bullet$ B - the upper part of the Monte Cocco II section: the Silurian-Devonian boundary is likely between beds $5 \mathrm{D}$ and $5 \mathrm{E}$. $\bullet \mathrm{C}$ - bioclastic wackestone, sample, MC II 2, crispa Zone; scale bar $=2 \mathrm{~mm}$. $\bullet \mathrm{D}-$ bioclastic grainstone with a large orthoceratid shell, sample MC II 6, woschmidti Zone; scale bar = $2 \mathrm{~mm}$. $\bullet$ E - bioclastic wackestone, sample MC II 5, detortus Zone; scale bar = 2 mm.

$13^{\circ} 26^{\prime} 47^{\prime \prime}$ (Fig. 1). The section consists of about 17 metres of Orthoceras limestone (Figs 2, 3) that are divided into three lithostratigrapic units: "Alticola Limestone", Rauchkofel Formation and Boden Limestone.

The lower part of the section exposes about $14 \mathrm{~m}$ of "Alticola Limestone": a grey-pale brownish cephalopod wackestone, which in some intervals turns dark red due to weathering of abundant iron minerals. The upper part of the unit is more greyish in colour and progressively grades to the grey packstone of the neritic Rauchkofel Fm. $(1.5 \mathrm{~m})$. The upper part of the section is represented by about $1.5 \mathrm{~m}$ of well-bedded, pale-grey-whitish limestone of the Boden Limestone. However, it should be pointed out that it is difficult to precisely locate unit boundaries because they are gradational and also because of weathering.

Nautiloid cephalopods, trilobites and bivalves are abundant throughout the section, whereas crinoids, gastropods and brachiopods are rare. The dominant microfacies is cephalopod wackestone and packstone (Fig. 2C-E). Thin-section analysis revealed echinoderms, gastropods, and cephalopods; small shells (ostracods, bivalves and brachiopods) were also present.

\section{Conodont fauna}

Twenty-six samples were processed with the conventional formic acid technique. More than $65 \mathrm{~kg}$ of limestone yielded about 1700 conodont elements (Table 1). The state of preservation is generally quite good, even if a few elements are broken or slightly deformed. The abundance varies from 136 elements/kg (sample MC II 1A) to 2 elements/kg (sample MC II 8), with an average of about 25 elements $/ \mathrm{kg}$. In general, the lower part of the section has a much greater abundance of conodont elements, while the upper part (Boden Lms) has low abundance. Conodont colour is dark brown, corresponding to a Colour Alteration Index of 3.5-4.

Twenty-seven taxa belonging to fourteen genera were identified: Belodella, Coryssognathus, Dapsilodus, Dvorakia, Icriodus, Lanea, Oulodus, Ozarkodina, Panderodus, Pedavis, Pelekysgnathus, Pseudooneotodus, Wurmiella and Zieglerodina.

Ozarkodinids are always very abundant throughout the section, representing approximately one half of the entire fauna. Coniforms (mainly Dapsilodus and Panderodus) are only dominant in the lower part of the section, up to sample MC II 1A.

\section{Biostratigraphy}

The biozonation schemes followed in this paper are those proposed by Corradini \& Serpagli (1999) for the Silurian and by Carls \& Weddige (1996) for the Lower Devonian. However, it is necessary to point out that the Přídolí zonation of Corradini et al. (1998), Corradini \& Serpagli (1999) 


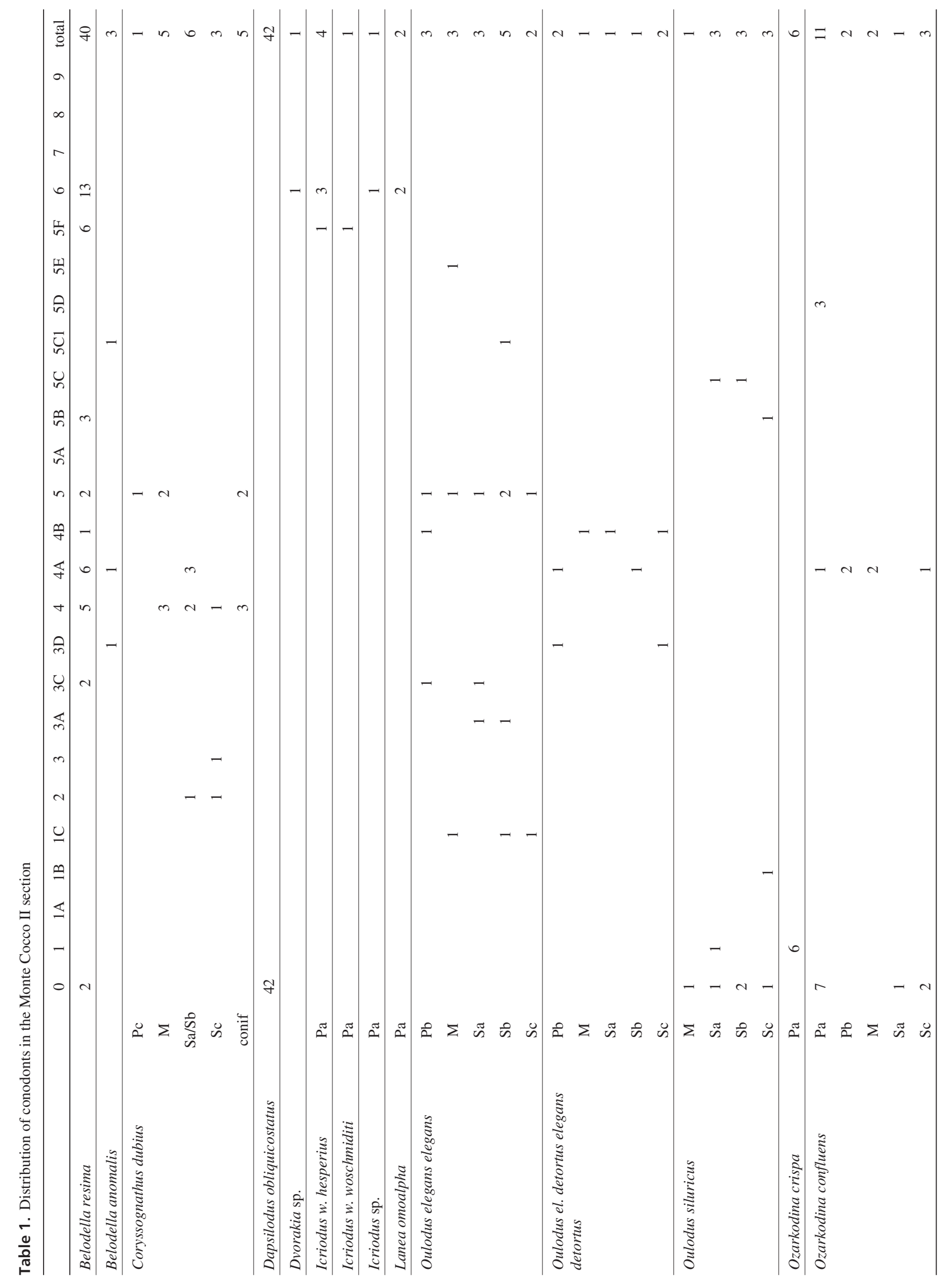




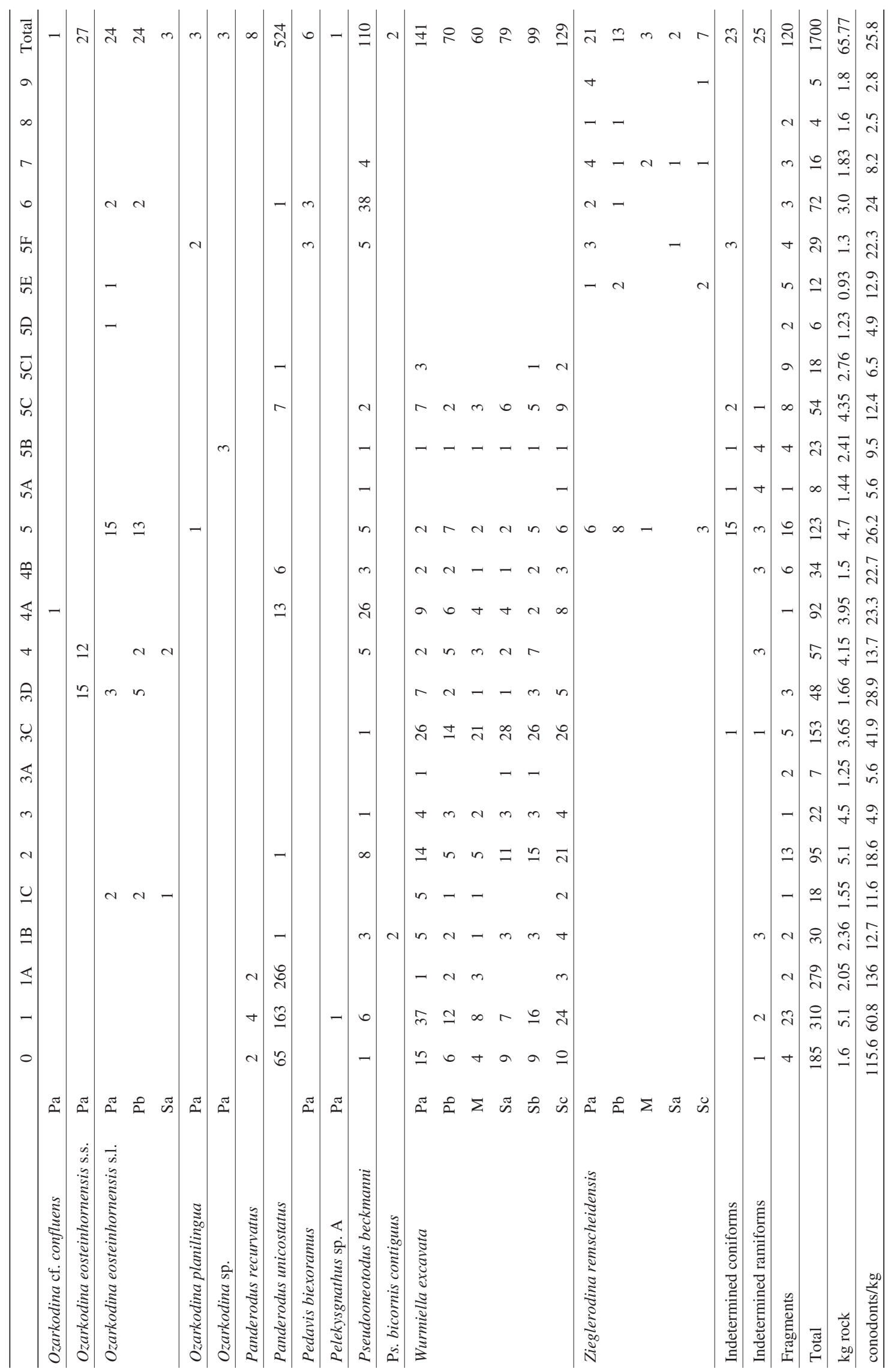


should be updated, as already suggested by Corriga et al. (2009). The authors named an "Oz. rem. remscheidensis interval Zone" in the lower Přídolí, defining an interval between the last occurrence of Ozarkodina crispa and the first occurrence of Oulodus elegans detortus. However, recent taxonomic revisions of late Silurian Ozarkodinids by Murphy et al. (2004) and Carls et al. (2007) state that Zieglerodina remscheidensis (Ziegler) is restricted to the Lower Devonian and does not occur in the lower part of Přídolí. Therefore, it is not appropriate to name a zone by an absent taxon. Awaiting a careful taxonomic revision of Prídolian Ozarkodinids, we choose to rename the "Oz. rem. remscheidensis interval Zone" of Corradini \& Serpagli (1998, 1999) after the more common taxon: Ozarkodina eosteinhornensis s.l. It should be pointed out that this name variation does not change the biostratigraphic meaning of the zone, since the definition of the boundaries remains the same.

The conodont association allows recognition of five conodont zones in the Monte Cocco II Section: snajdri, crispa, eosteinhornensis s.l. and detortus Zones in the Silurian and the woschmidti Zone in the Devonian.

The snajdri Interval Zone. - No markers are present in sample MC II 0. However, the occurrence of Ozarkodina crispa (marker of the crispa Zone) in sample MC II 1 allows us to state that the strata below belong to the immediately older snajdri Zone. According to Corradini \& Serpagli (1999) the upper limit of the snajdri interval Zone is defined by the first occurrence of Oz. crispa. Panderodus unicostatus and Dapsilodus obliquicostatus are abundant in this interval; a similar abundance of these taxa also occur in coeval levels in the Cellon section, and may be related to regional ecologic factors.

The crispa Zone. - The lower boundary of the crispa Zone is defined by the first occurrence of the marker Oz. crispa, and the upper boundary by the last occurrence of the same taxon. It has been found only in sample MC II 1 and therefore only this level belongs to the crispa Zone. Panderodus unicostatus is dominant, and Wurmiella excavata is also very abundant.

The eosteinhornensis s.l. interval Zone. - The eosteinhornensis s.l. Zone is distinguished from sample 1A to sample $3 \mathrm{C}$ in that the lower boundary is defined by the last occurrence of $\mathrm{Oz}$. crispa, and the upper boundary is defined by the first occurrence of Oulodus el. detortus. Wurmiella excavata is largely dominant in all the levels of this interval, with the exception of sample MC II 1A, where Panderodus unicostatus represents more than $90 \%$ of the association.

The detortus Zone. - The detortus Zone occurs in samples $3 \mathrm{D}$ to $5 \mathrm{E}$. The lower boundary is defined by the first occurrence of Oulodus elegans detortus, and the upper boundary by the entry of Icriodids (either I. woschmidti or I. hesperius). The marker has not been found in the upper part of the Zone, since it has its last occurrence in sample MC II 4B.

For a long time after Jeppsson's (1988) paper on the Silurian/Devonian GSSP, the Klonk section, Oul. el. detortus was considered the uppermost Přídolí marker, just below the Silurian/Devonian boundary. However, it has been recently demonstrated that this taxon already occurs by around the middle of the Prídolí in several geographic areas, such as Sardinia (Gouwy \& Corradini 2006), the Czech Republic (Požáry section; Carls et al. 2007) and Frankenwald (Carls et al. 2007). This is also the case in the Monte Cocco II section; therefore this zone is also definitely longer in the Carnic Alps.

The woschmidti Zone. - The joint first occurrence of I. woschmidti and I. hesperius in sample 5F allows us to refer this beds and the upper part of the section to the woschmidti Zone. However, the entry of Pe. biexoramus in the same sample suggests that this level is in the high part of the zone. For discussion on the Silurian/Devonian boundary see below.

\section{Comments on the Silurian/Devonian boundary}

Recognizing the Silurian/Devonian boundary on the basis of conodonts has always been a problem because the boundary is defined by the first occurrence of the graptolite $\mathrm{Mo}$ nograptus uniformis, and no known conodont taxon has a simultaneous first occurrence.

Icriodus woschmidti is the marker of the first conodont zone of the Lochkovian and its presence is often considered as a proof of Devonian age. However, according to Jeppsson (1988), in many sections I. woschmidti occurs slightly before $M$. uniformis, but this fact may be due to facies control: graptolites are normally collected from shales and conodonts from limestones. Furthermore Icriodids are typical of inshore shallow water deposits (Bultynck 2003), but are rare in other marine environments. As a result I. woschmidti is very rare, if not absent, in many sections. It should be pointed out that possible problems in the discrimination of I. woschmidti from I. hesperius may occur

Figure 3. Stratigraphic log of the Monte Cocco II section, with indication of stratigraphic units and occurrence of main conodont taxa. Numbers on the right of the column indicate conodont samples. 
Maria G. Corriga \& Carlo Corradini • Upper Silurian and Lower Devonian conodonts from the Carnic Alps

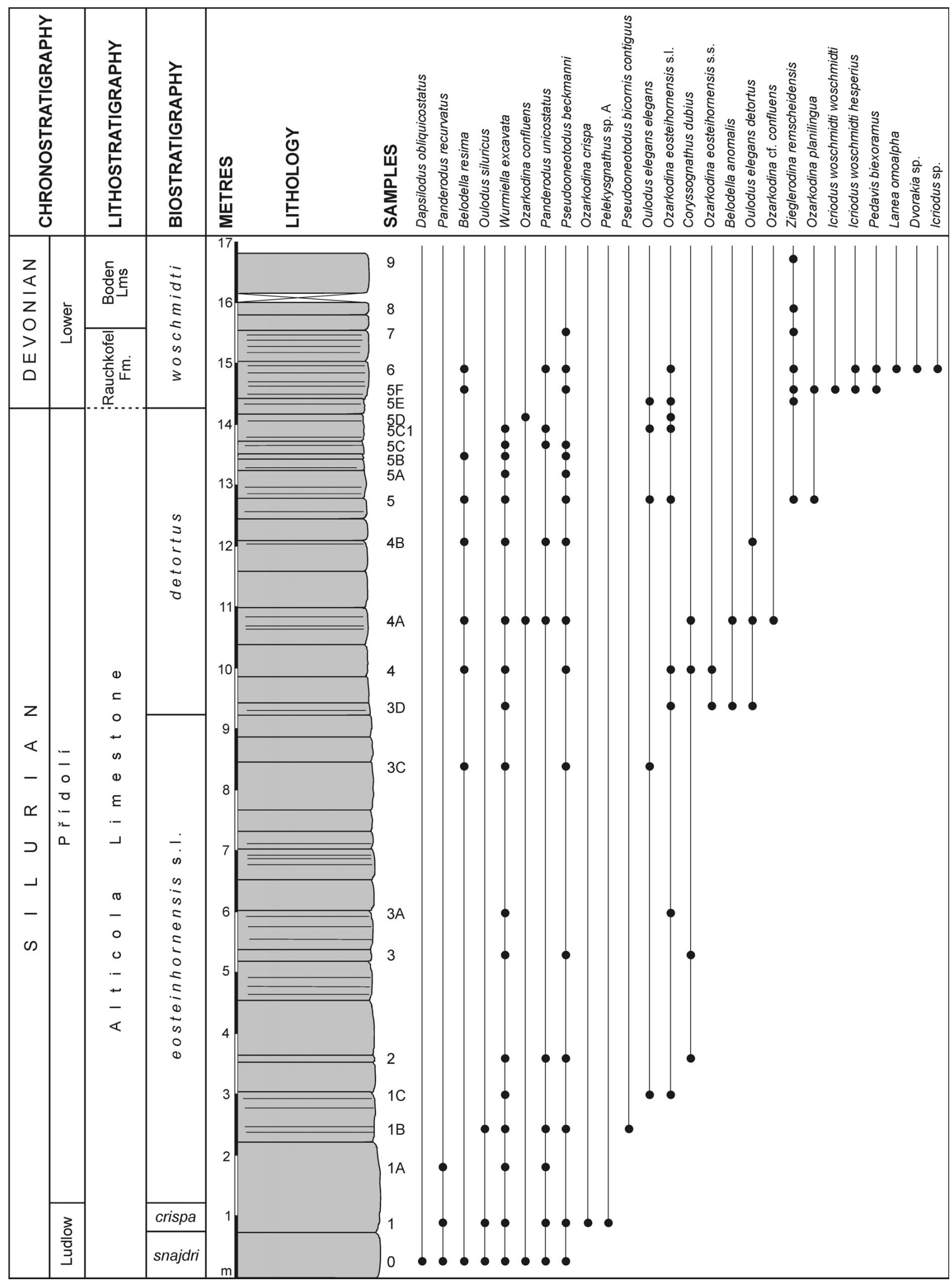


and in several localities the latter species has an older first occurrence (M. Murphy, pers. comm.). Therefore the entry of one or the other Icriodus taxon may be used for recognizing a basal Devonian age.

Jeppsson (1988, fig.1) draws the S/D boundary more or less coincident with the top of the L. e. detorta Zone (here detortus Zone). In some areas Oulodus elegans detortus has a longer range within the Přídolí (Gouwy \& Corradini 2006, Carls et al. 2007), but Oul. el. detortus always becomes extinct just below the base of the Devonian and before the entry of Icriodus woschmidti and/or I. hesperius.

The Silurian/Devonian boundary, therefore, should be located between the last occurrence of Oulodus elegans detortus and the first occurrence of Icriodus woschmidti and/or I. hesperius. In the Monte Cocco II section Oul. el. detortus has its last occurrence in sample MC II 4B, whereas Icr. hesperius occurs 2.5 metres above in sample MC II 5F together with Pedavis biexoramus. The latter species has been reported somewhat higher within the uniformis graptolite Zone, after the last occurrence of I. hesperius (Schönlaub 1980) or slightly higher (eurekaensis Zone of Murphy \& Matti 1982); therefore that level may not correspond to the base of the woschmidti Zone.

Oz. confluens (= Oz. typica sensu Murphy et al., 2004) does not reach the Devonian (M. Murphy, pers. comm.), and in the Monte Cocco II section is discontinuously present up to sample MC II 5D. Zieglerodina remscheidensis appears in sample MC II 5 and then is present continuously from MC II 5E and above. Murphy et al. (2004) introduced the genus Zieglerodina and revised the type species, stating that $Z$. remscheidensis has a restricted range in the early Lochkovian, but gave no key for determination of many other morphotypes strictly related to this species and previously identified as "Oz. remscheidensis". Our material from sample MC II 5 is represented by poorly preserved small elements, whereas specimens from sample MC II 5E show typical features of Z. remscheidensis sensu Murphy et al. (2004). Thus, it is possible that in that restricted taxonomic interpretation and after a complete revision of species belonging to genus Zieglerodina, the specimens from sample MC II 5 represent some early form of Z. remscheidensis, whereas late forms of the species occur near the base of the Devonian. Unfortunately, our material is not preserved well enough to make any decisive conclusion.

On the basis of our findings, the Silurian/Devonian boundary can be tentatively placed in the Monte Cocco II section between sample MC II 5D and sample MC II 5E.

\section{Systematic palaeontology}

Systematic notes are restricted to necessary taxonomic or biostratigraphic remarks. For suprageneric classification, the scheme proposed by Sweet (1988) is followed.
The studied material is stored in the Earth Science Department of the University of Cagliari; figured specimens are housed in the Palaeontological Museum of the University of Modena and Reggio Emilia (IPUM); horizons and catalogue numbers are given in the figure captions.

Phylum Chordata Bateson, 1886

Class Conodonta Pander, 1856

Order Ozarkodinida Dzik, 1976

Family Spathognathodontodae Hass, 1959

\section{Genus Ozarkodina Branson \& Mehl, 1933}

Type species. - Ozarkodina confluens Branson \& Mehl, 1933.

Remarks. - The genus Ozarkodina was recently subdivided into several new genera by Murphy et al. (2004) and Carls et al. (2005). We agree with these authors that in the previous meaning Ozarkodina included several different groups which may represent separate genera; however, in our opinion, this new scheme may be imperfect as well. Wurmiella has been proposed to include taxa related to the "excavata Group", while Zieglerodina is the new genus name for the "remscheidensis Group". These subdivisions seem to be valid and the names accepted, apart from some possible nomenclature problems highlighted by Donoghue et al. (2008). Murphy et al. (2004) also proposed a new genus to represent the "eosteinhornensis Group", which has not been accepted according to ICZN rules. We believe that the apparatus structure and the morphology of the elements in this group are very close to that of the "remscheidensis Group," and therefore could belong to the genus Zieglerodina. However, since there is still ongoing debate in the scientific community as to the affinity of this group, and our material is not sufficient to reach a definitive solution, we refer to taxa of the latter group as "Ozarkodina" eosteinhornensis in the remainder of this paper. A few other taxa, such as "Ozarkodina" snajdri (Walliser) and "Ozarkodina" crispa (Walliser) still do not have a home after this subdivision, because their apparatuses remain unknown.

\section{Ozarkodina cf. confluens Branson \& Mehl, 1933} Figure 4N

1964 Spathognathodus primus (Branson \& Mehl). - Walliser, pl. 22, fig. 16 (only).

1975 Ozarkodina confluens (Branson \& Mehl). - Klapper $\&$ Murphy, p. 68, pl. 4, figs 24, 25 (only). 


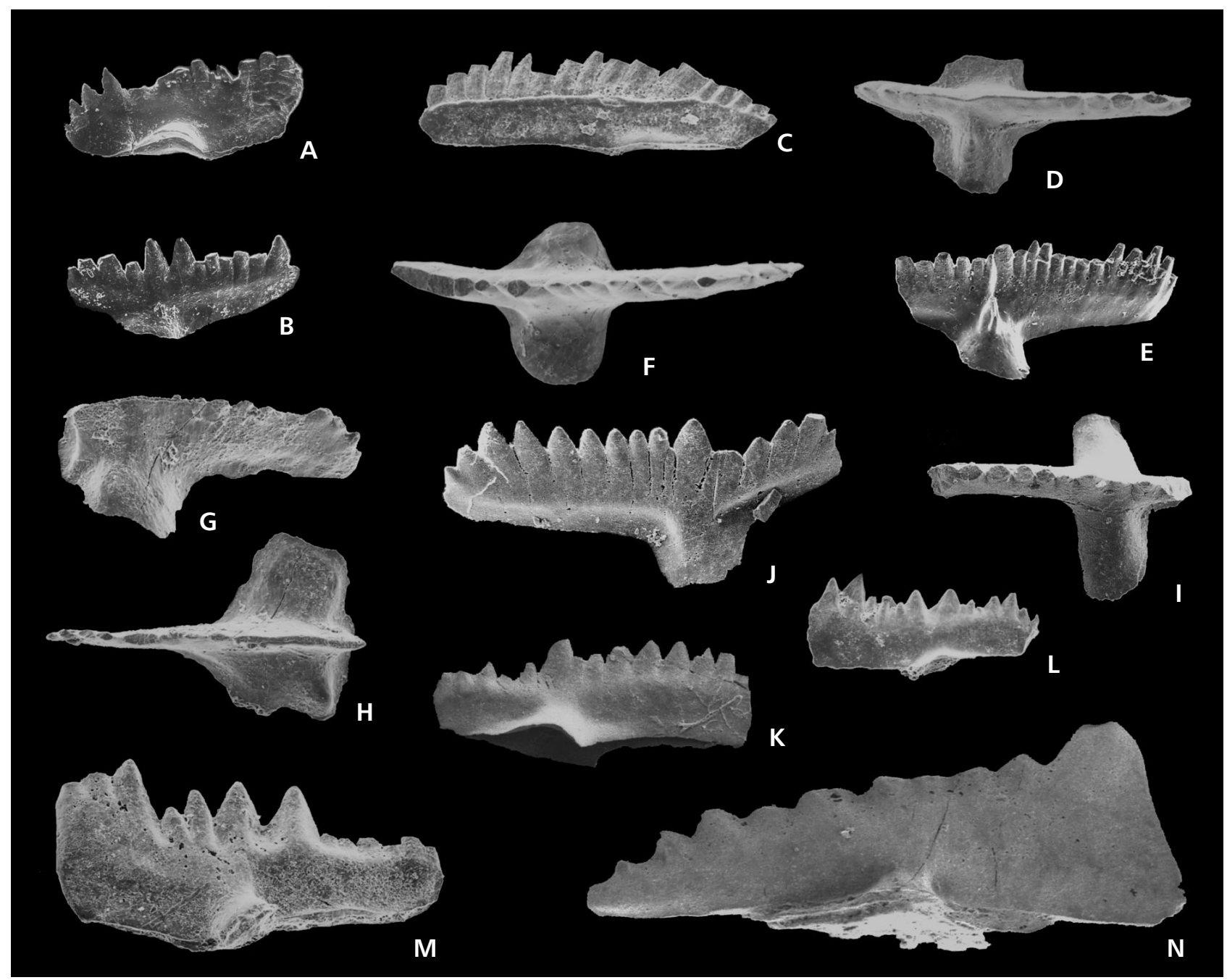

Figure 4. A - Zieglerodina cf. remscheidensis (Ziegler, 1960); IPUM 28203, lateral view of Pa element, sample MC II 5, detortus Zone; $\times 70$. - B - Zieglerodina cf. remscheidensis (Ziegler, 1960); IPUM 28204, lateral view of Pa element, sample MC II 5 detortus Zone, $\times 70$. $\bullet$ C Wurmiella excavata (Branson \& Mehl, 1933); IPUM 27671, lateral view of Pa element; sample MC II 1, Oz. crispa Zone; $\times 70$. D - Ozarkodina eosteinhornensis s.s. (Walliser, 1964); IPUM 27673, upper view of Pa element; sample MC II 3D, eosteinhornensis s.1. Zone; $\times 70$. E - Ozarkodina eosteinhornensis s.s. (Walliser, 1964); IPUM 27674, lateral views of Pa element; sample MC II 3D, eosteinhornensis s.l. Zone; $\times$ 70. F - Ozarkodina eosteinhornensis s.1. (Walliser, 1964); IPUM 27672, upper view of Pa element; sample MC II 3D, eosteinhornensis s.1. Zone; $\times$ 70. • G, H - Ozarkodina crispa (Walliser, 1964); IPUM 27677, lateral (G) and upper (H) views of Pa element; sample MC II 1, crispa Zone; $\times 70$. • I - Lanea cf. omoalpha (Murphy \& Valenzuela-Ríos, 1999); IPUM 28205 upper view of Pa element, sample MC II 6, woschmidti Zone; $\times 70$. • J - Ozarkodina planilingua (Murphy \& Valenzuela-Rios, 1999); IPUM 28192, upper-lateral view of Pa element; sample MC II 5F, woschmidti Zone; $\times 70$. $・$ K - Ozarkodina planilingua (Murphy \& Valenzuela-Rios, 1999); IPUM 28191, lateral view of Pa element; sample MC II 5F, woschmidti Zone; $\times 70$. $\bullet$ L - Ozarkodina confluens (Branson \& Mehl, 1933); IPUM 27680, lateral view of Pa element; sample MC II 0, snajdri Zone; $\times$ 70. • M - Ozarkodina confluens (Branson \& Mehl, 1933); IPUM 27681, lateral view of Pa element; sample MC II 4A, eosteinhornensis s.l. Zone; $\times 70$. $・$ N - Ozarkodina cf. confluens (Branson \& Mehl, 1933); IPUM 28193, lateral view of Pa element; sample MC II 4A, detortus Zone; $\times 45$.

Description. - The single Pa element recovered has a general triangular outline in lateral view, since the blade is definitely higher in the anterior part and declines steeply towards the posterior end. A distinct set of two fused denticles is located in the anterior part of the blade; nine denticles are on the remaining part of the blade; denticles well spaced, almost fused and laterally compressed. The subtriangular basal cavity is located under the central part of the element.
Remarks. - The studied specimen is close to Oz. confluens in the general shape, but the denticles pattern and the strongly subtriangular outline of the blade are not typical; therefore, we prefer to name it $O z$. cf. confluens. It is similar to representatives of genus Amydrotaxis in having spaced and partially fused denticles, but differs in the shape of basal cavity, which does not reach the extremities of the blade. Similar elements have been figured by Walliser (1964), and reported as $O z$. confluens delta morphotype by Klapper \& Murphy (1975). 


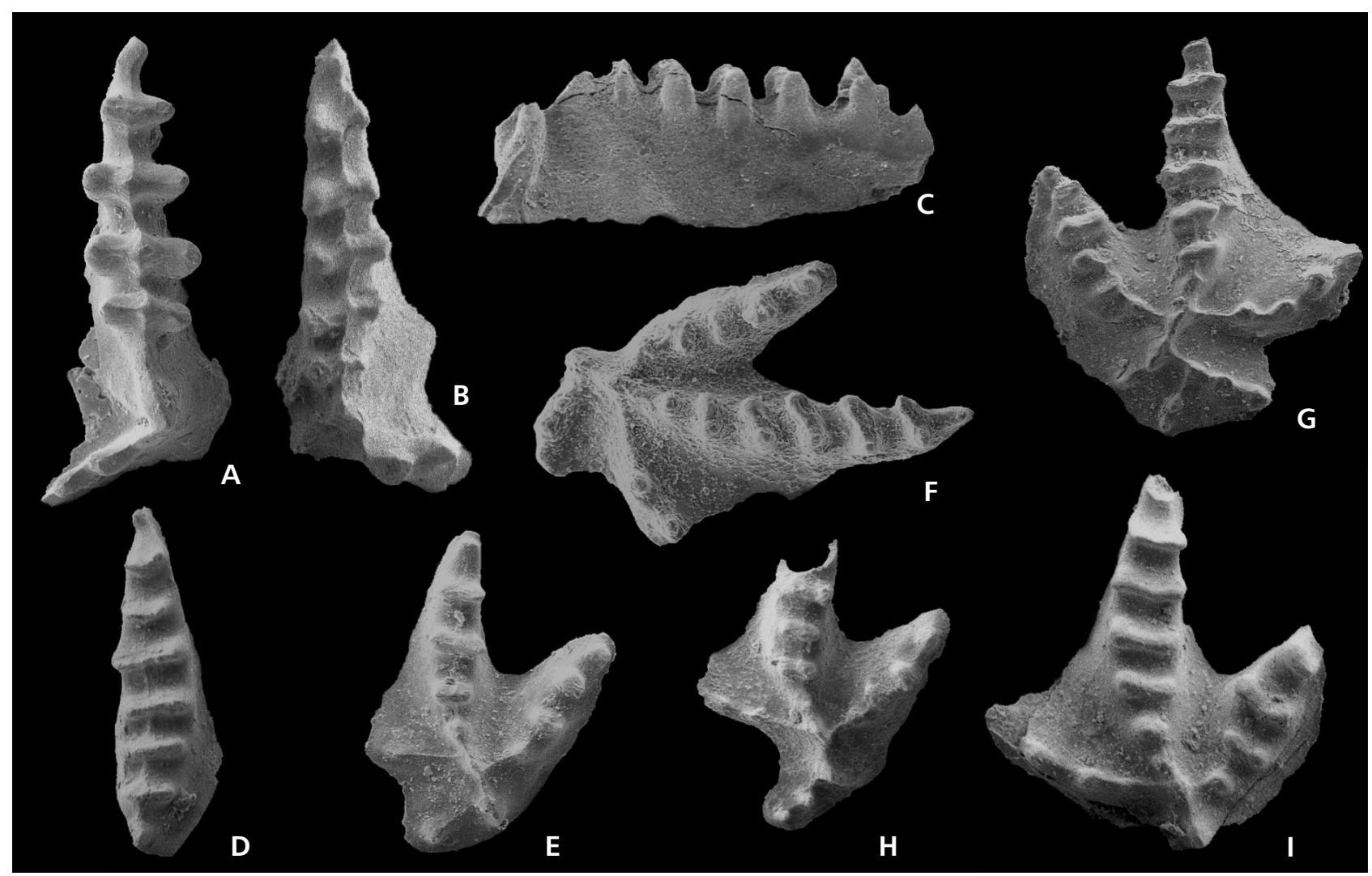

Figure 5. A - Icriodus woschmidti woschmidti (Ziegler, 1960); IPUM 28196, upper view; sample MC II 5F, woschmidti Zone; × 70. • B, C - Icriodus woschmidti hesperius (Klapper \& Murphy, 1975); IPUM 28195, upper (B) and lateral (C) views; sample MC II 5F, woschmidti Zone; $\times 45$. D - Icriodus sp.; IPUM 28197, upper view; sample MC II 6, woschmidti Zone; $\times$ 70 • E - Pedavis biexoramus (Murphy \& Matti, 1982); IPUM 28201, upper view; sample MC II 5F, woschmidti Zone; $\times 70$. $\bullet \mathrm{F}-$ Pedavis biexoramus (Murphy \& Matti, 1982); IPUM 28200, upper view; sample MC II 5F, woschmidti Zone; $\times 70 . \bullet \mathrm{G}-$ Pedavis biexoramus (Murphy \& Matti, 1982); IPUM 28199, upper view; sample MC II 5F, woschmidti Zone; $\times 70 . \bullet \mathrm{H}-$ Pedavis biexoramus (Murphy \& Matti, 1982); IPUM 28202, upper view; sample MC II 6, woschmidti Zone; $\times$ 70. • I - Pedavis biexoramus (Murphy \& Matti, 1982); IPUM 28198, upper view; sample MC II 6, woschmidti Zone; × 70.

Stratigraphic range. - The studied specimen comes from the eosteinhornensis s.l. interval Zone. The specimen figured by Walliser (1964), also from the Carnic Alps, is from the same stratigraphic level, whereas specimens figured by Klapper \& Murphy (1975) are definitely older.

Material. - 1 Pa element from sample MC II 4A.

Order Prioniodontida Dzik, 1976

Family Icriodontidae Müller \& Müller, 1957

\section{Genus Pedavis Klapper \& Philip, 1971}

Type species. - Icriodus pesavis Bischoff \& Sannemann, 1958.

\section{Pedavis biexoramus Murphy \& Matti, 1982}

Figures 5E-I

1975 Pedavis sp. nov. C. - Klapper \& Murphy, p. 50, pl. 12, fig. 12 .
1979 Pedavis sp. - Lane \& Ormiston, pl. 1, fig. 14.

1980 Pedavis cf. biexoramus Murphy et al. - Schönlaub, pl. 1, fig. 14.

1982 Pedavis biexoramus n. sp. - Murphy \& Matti, pp. 51-54, pl. 5, figs 28,33

1992 Pedavis biexoramus Murphy \& Matti. - Barrick \& Klapper, p. 45, pl. 3, figs 1-3.

Remarks. - The specimens of P. biexoramus from the Monte Cocco II section are similar to the type material described by Murphy \& Matti (1982). All have well developed inner and outer processes, except the specimen in Fig. 6G, which has a weak process.

Stratigraphic range. - P. biexoramus is known from the lowermost Devonian of the Carnic Alps from the Oberbuchach 2 Section [slightly above the last occurrence of Icriodus woschmidti (Schönlaub, 1980)], and in Nevada from within the eurekaensis Zone (Murphy \& Matti 1982). However, a possible earlier origin of the species within the hesperius Zone is suggested by Murphy \& Matti (1982, fig. 9), 


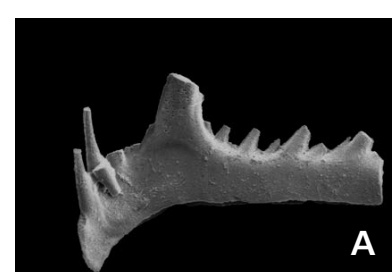

A

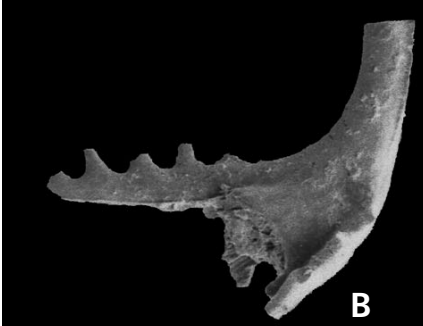

C

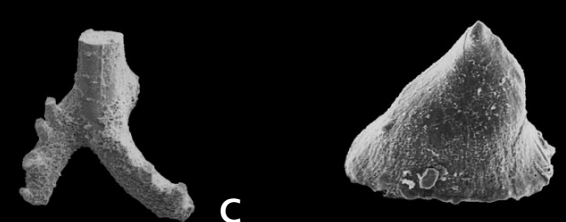

D

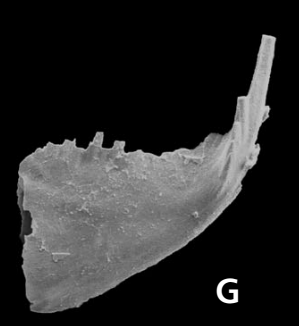

G
E
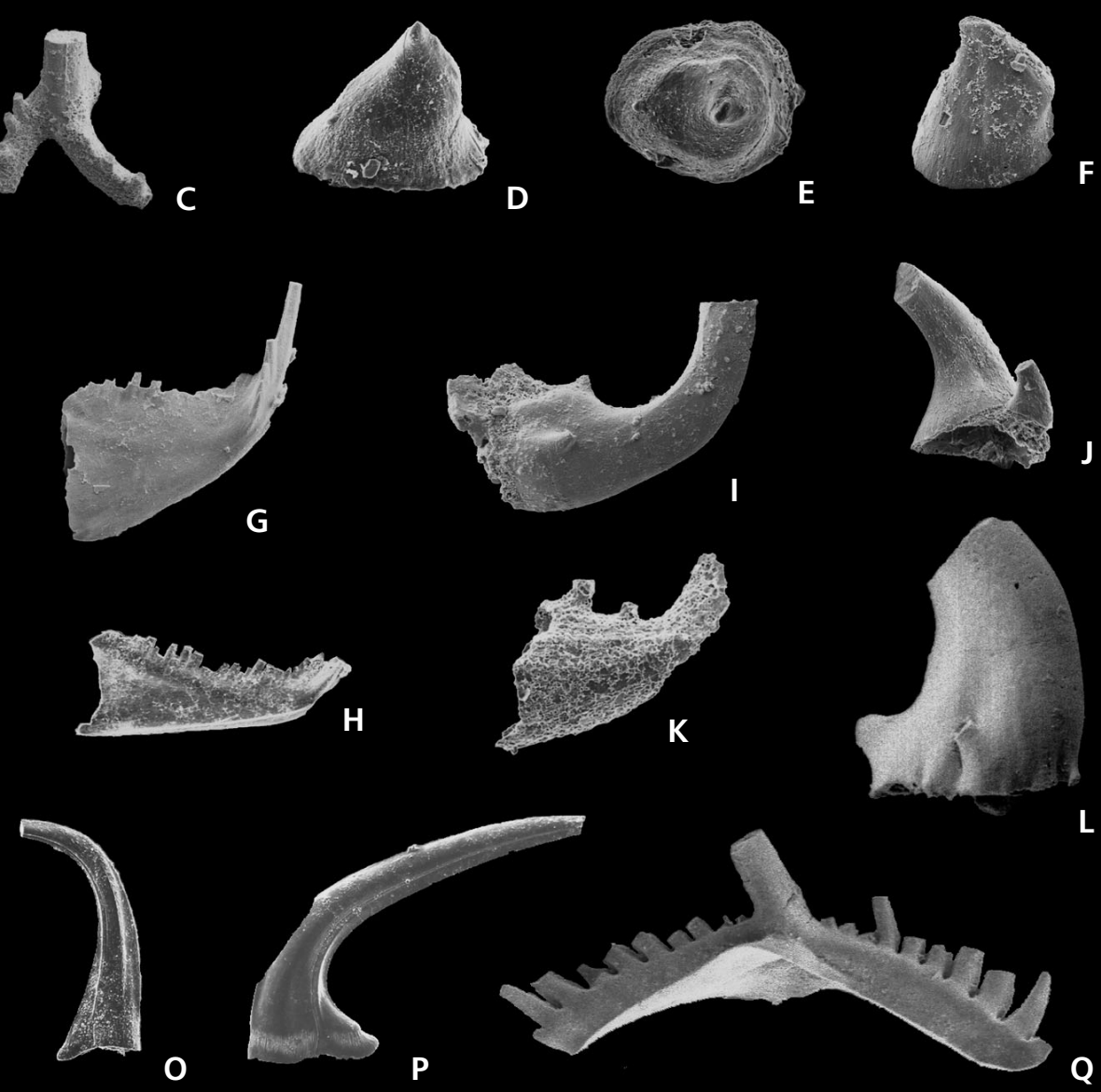

Figure 6. A - Oulodus elegans detortus (Walliser, 1964); IPUM 28180, lateral view of Sc element, sample MC II 3D, detortus Zone; $\times 70$. - B - Oulodus elegans elegans (Walliser, 1964); IPUM 28181, lateral view of Sc element, sample MC II 5, detortus Zone; $\times 70$. $\bullet$ C - Oulodus elegans elegans (Walliser, 1964); IPUM 28182, posterior view of Pb element, sample MC II 3C, detortus Zone; $\times 70 . \bullet \mathrm{D}$, E - Pseudooneotodus beckmanni (Bischoff \& Sannemann, 1958); IPUM 27678, lateral (D) and upper (E) views, sample MC II 1, crispa Zone; $\times 90 . \bullet$ F - Pseudooneotodus bicornis contiguus (Corradini, 2008); IPUM 28183, lateral view; sample MC II 1B, eosteinhornensis s.l. Zone; $\times 90 . \bullet \mathrm{G}-$ Belodella anomalis (Cooper, 1974); IPUM 28184 , lateral view; sample MC II 3D, detortus Zone; $\times 70$. $\bullet \mathrm{H}-$ Belodella resima (Philip, 1965); IPUM 27675, lateral view of Pa element; sample MC II 4 , eosteinhornensis s.l. Zone; $\times 70$. $・$ I - Coryssognathus dubius (Rhodes, 1953); IPUM 28187, lateral view of Sa/Sb element; sample MC II 4, detortus Zone; $\times 70$. $-\mathrm{J}-$ Coryssognathus dubius (Rhodes, 1953); IPUM 28186, lateral view of M element; sample MC II 4, detortus Zone; $\times 70$. $\bullet \mathrm{K}$ - Coryssognatus dubius (Rhodes, 1953); IPUM 27683, lateral view of Sc element; sample MC II 4, detortus Zone; $\times 70 . \bullet \mathrm{L}-$ Coryssognathus dubius (Rhodes, 1953); IPUM 28188, lateral view of Sa/Sb element; sample MC II 4, detortus Zone; × 70. • M - Pelekysgnathus sp. A (Thomas, 1949); IPUM 28190, lateral view of Pa element; sample MC II 1, crispa Zone; $\times$ 70. $・$ N - Dapsilodus obliquicostatus (Branson \& Mehl, 1933); IPUM 28189, lateral view; sample MC II 0, crispa Zone; $\times$ 50. $\bullet$ O - Panderodus unicostatus (Branson \& Mehl, 1933); IPUM 28185, lateral view; sample MC II 1, crispa Zone; $\times 50$. $\bullet P-$ Panderodus recurvatus (Branson \& Mehl, 1933); IPUM 28206, lateral view; sample MC II 1 , crispa Zone; $\times 50$. $\bullet Q-$ Oulodus siluricus (Branson \& Mehl, 1933); IPUM 28194, lateral view of Pb element; sample MC II 5C, detortus Zone; $\times 45$.

and also on the basis of joint occurrences at Copenhagen Canyon V-IV (Murphy \& Matti 1982, tab. 1). Our material appears to confirm their hypothesis, because it comes from samples where Icriodus hesperius is also present.

Material. -6 Pa elements from samples MC II 5F-MCII 5.

\section{Genus Pelekysgnathus Thomas, 1949}

Type species. - Pelekysgnathus inclinatus Thomas, 1949.

\section{Pelekysgnathus sp. A} Figure 6M

1995 Pelekysgnathus index Klapper \& Murphy. - Barca et al., pl. 4, figs 4, 5.

1998 Pelekysgnathus index Klapper \& Murphy. - Serpagli et al., p. 110, pl. 1.2.2, figs 4, 5

Description. - The element is small, laterally compressed and with the anterior end slightly bent downward. The blade bears denticles that are partially fused, laterally com- 
pressed and of different size. The posteriormost denticle is strongly posteriorly directed and looks bigger than the other denticles, even if broken. The basal cavity is symmetrical, oval and not very wide; it is located under the posterior third of the element.

Remarks. - The posterior position of the basal cavity and the features of the posterior denticle allow us to refer the specimen to the Genus Pelekysgnathus. This taxon differs from $P$. index in having a smaller and almost symmetrical basal cavity, a less developed posterior denticle and much more differentiated denticles.

Similar specimens have been found in Sardinia by Barca et al. (1995) and Serpagli et al. (1998) from the lowermost part of the crispa Zone.

Stratigraphic range. - Our specimen and those figured in literature are all from the lower part of the crispa Zone.

Material. - 1 Pa element from samples MC II 1.

Family Pterospathodontidae Cooper, 1977

Genus Coryssognathus Link \& Druce, 1972

Type species. - Cordylodus? dubius Rhodes, 1953.

\section{Coryssognathus dubius (Rhodes, 1953)}

Figures 6I-L

1993 Coryssognathus dubius (Rhodes). - Miller \& Aldridge, p. 243-253, pl. 1, figs 1-14; pl. 2, figs 1-18; pl. 3, figs $1-12$; pl. 4, figs $1-15$; text-figs $2-6$ (cum syn.).

1997 Coryssognathus dubius (Rhodes). - Serpagli et al., pp. 240-242, pl. 1, figs 1-15 (cum syn.).

1998 Coryssognathus dubius (Rhodes). - Corradini et al., pl. 3.3.1, fig. 15 .

1999 Coryssognathus dubius (Rhodes). - Viira, pl. 1, figs 9-12.

1999 Coryssognathus dubius (Rhodes). - Cockle, p. 120, pl. 4 , fig. 20.

2001 Coryssognathus dubius (Rhodes). - Corradini et al., pl. 1, figs 10, 11 .

2003 Coryssognathus dubius (Rhodes). - Corradini et al., pl. 1, fig. 13.

2004 Coryssognathus dubius (Rhodes). - Farrell, pp. 959, 960, pl. 4, figs 1-9.

Remarks. - The apparatus of Coryssognathus dubius was reconstructed as septimembrate by Miller \& Aldridge (1993) and their proposal was followed by Serpagli et al. (1997). The taxon is documented in several palaeoconti- nents, but only from Llandovery-Ludlow; however, in northern Gondwana it appears to have a longer range, nearly reaching the top of the Silurian (i.e. Sardinia, Serpagli et al. 1997). The taxon occurs in the Monte Cocco II section up to the lower part of the detortus Zone, and is found in levels where $O z$. eosteinhornensis s.s. has also been recovered, confirming the range documented in Sardinia. Therefore, it appears that $C$. dubius has a longer range in northern Gondwana than elsewhere.

Stratigraphic range. - The species in known from the late Llandovery (Mabillard \& Aldridge 1983) to the uppermost Silurian (Serpagli et al. 1997, and this paper).

Material. - $1 \mathrm{Pc}, 5 \mathrm{M}, 6 \mathrm{Sa} / \mathrm{Sb}, 3 \mathrm{Sc}$ and 5 coniform elements, from samples MC II 2, MC II 3, MC II 4, MC II 4A and MC II 5.

\section{Conclusions}

The main results of this paper can be summarized as follows:

1. the conodont association allows the discrimination of five late Silurian-lowermost Devonian conodont zones: snajdri, crispa, eosteinhornensis s.l., detortus and woschmidti;

2. the Silurian/Devonian boundary occurs in the upper part of the section. However, it is not possible to locate it accurately; it can be constrained within a small interval between the last occurrence of $\mathrm{Oz}$. confluens (MC II 5D) and the first occurrence of Icriodontids (MC II 6). Furthermore, the occurrence of typical forms of $Z$. remscheidensis in sample MC II 5E indicates that this level is likely Devonian in age;

3. a new species of Pelekysgnathus is described from the crispa Zone, and left in open nomenclature. This taxon is potentially useful for regional correlation within northern Gondwana;

4. Coryssognathus dubius reaches the upper part of the detortus Zone, occurring together with Oz. eosteinhornensis s.s., confirming its longer range (up to the Přídolí) in northern Gondwana.

\section{Acknowledgements}

Luca Simonetto (Udine), Monica Pondrelli (Pescara) and Paolo Serventi (Modena) shared the work in the field, providing useful comments on the geology of the area. Angelo Ibba (Cagliari) and 
Claudio Gentilini (Modena) took scanning microscope pictures and Salvatore Vacca (Cagliari) helped in the laboratory. Mike Murphy (Riverside) and Ladislav Slavík (Prague) critically read the manuscript providing useful comments. This paper is a contribution to IGCP Project No. 499 "Devonian sea-land interactions: evolution of ecosystem and climate".

\section{References}

Barca, S., Corradini, C., Ferretti, A., Olivieri, R. \& SeRPAGLI, E. 1995. Conodont biostratigraphy of the "Ockerkalk" (Silurian) from southeastern Sardinia. Rivista Italiana di Paleontologia e Stratigrafia 100(4), 459-476.

BARRICK, J.E. \& KLAPPER, G. 1992. Late Silurian-Early Devonian conodonts from the Hunton Group (Upper Henryhouse, Haragan, and Bois d'Arc Formations), South-Central Oklahoma. Oklahoma Geological Survey Bulletin 145, 19-65.

BAteson, W. 1886. The Ancestry of the Chordata. Quarterly Journal of Microscopical Science 104, 535-572.

BischofF, G. \& SANNEMANN, D. 1958. Unterdevonische Conodonten aus dem Frankenwald. Notizblatt des hessisches Landesamt für Bodenforschung zu Wiesbaden 86, 87-110.

BRAnson, E.B. \& MEHL, M.G. 1933. Conodonts from the Bainbridge (Silurian) of Missouri. University of Missouri Studies 8(1), 39-52.

Bultynck, P. 2003. Devonian Icridontidae: biostratigraphy, classification and remarks on paleoecology and dispersal. Revista Española de Micropaleontologia 35(3), 295-314.

CARls, P., Slavík, L. \& VAlenZuela-Ríos, J.I. 2005. A new Ludlow (Late Silurian) Spathognathodontidae (Conodonta) from Bohemia with incipient alternating denticulation. Neues Jahrbuch für Geologie und Paläontologie, Monatshefte 2005(9), 547-565.

CARls, P., SlavíK, L. \& VAlenZuela-Ríos, J.I. 2007. Revisions of conodont biostratigraphy across the Silurian-Devonian boundary. Bulletin of Geosciences 82(2), 145-164. DOI 10.3140/bull.geosci.2007.02.145

CARLS, P. \& Weddige, K. 1996. Conodonten-Zone, globale, aktuelle; Unterdevon. In WEDDIGE, K. (ed.) Devon-Korrelationtabelle. Senckenbergiana lethaea 76, 274.

COCKLE, P. 1999. Conodont data in relation to Time, Space and Environmental Relationships in the Silurian (Late Llandovery-Ludlow) Succession at Boree Creek (New South Wales, Australia). Abhandlungen der Geologisches Bundesanstalt 54, 107-133.

COOPER, B.J. 1977. Toward a familial classification of Silurian conodonts. Journal of Paleontology 51, 1057-1071.

Corradini, C., Ferretti, A. \& Serpagli, E. 1998. Wenlock and Pridoli conodonts from Argiola, East of Domusnovas, 194-198. In SerPagli, E. (ed.) Sardinia Guide-book, ECOS VII. Giornale di Geologia 60, Special Issue.

Corradini, C., LeONe, F., LOI, A. \& SERPAGLi, E. 2001. Conodont Stratigraphy of a highly tectonised Siluro-Devonian Sec- tion in the San Basilio area (SE Sardinia). Bollettino della Società Paleontologica Italiana 40, 315-323.

Corradini, C., Pondrelli, M., Serventi, P. \& Simonetto, L. 2003. The Silurian cephalopod limestone in the Monte Cocco area (Carnic Alps, Italy): Conodont biostratigraphy. Revista Española de Micropaleontologia 35(3), 285-294.

Corradini, C. \& SerPAGLI, E. 1999. A Silurian conodont zonation from late Llandovery to end Prídoli in Sardinia. Bollettino della Società Paleontologica Italiana 38(2-3), 255-273.

Corriga, M.G., Corradini, C. \& FERretTI, A. 2009 [in press]. Silurian conodonts from Sardinia: an overview. Rendiconti della Società Paleontologica Italiana 3, 13 pp.

DONOGHUE, P.C.J., PURNELl, M.A., ALDRIGE, R.J. \& ZHANG, S. 2008. The interrelationships of 'complex' conodonts (Vertebrata). Journal of Systematic Palaeontology 6(2), 119-153. DOI $10.1017 /$ S1477201907002234

DZIK, J. 1976. Remarks on the evolution of Ordovician conodonts. Acta Palaeontologica Polonica 21, 395-455.

FARRELL, J.R. 2004. Siluro-devonian conodonts from the Camelford Limestone, Wellington, New South Wales, Australia. Palaeontology 47(4), 937-982. DOI 10.1111/j.0031-0239.2004.00394.x

FERUGLIO, G.B. 1970. Il giacimento ferro manganesifero del Monte Cocco (Alpi Carniche). Museo Friulano di Storia Naturale, Pubblicazione 18, 1-43.

FRECH, F. 1888. Über das Devon der Ostalpen nebst Bermekungen über das Silur und einem paläontologischen Anhang. Zeitschrift der Deutschen Geologischen Gesellshaft 39, 659-738.

GouwY, S. \& CORRADINI, C. 2006. Graphic correlation of the Sardinian Ockerkalk (Upper Silurian): implications on the conodont biostratigraphy. GFF 128, 103-108.

HASS, W.H. 1959. Conodonts from the Chappel Limestone of Texas. U.S. Geological Survey Professional Paper 294, 365-399.

HerzoG, U. 1988. Das Paläozoikum zwischen Poludnig und Osternig in der Östlichen Karnischen Alpen. Carinthia 2(47), $1-123$.

JEPPSSON, L. 1988. Conodont biostratigraphy of the Silurian-Devonian boundary stratotype at Klonk, Czechoslovakia. Geologica et Palaeontologica 22, 21-31.

KLAPPER, G. \& MURPHY, M.A. 1975. Silurian-Lower Devonian conodont sequence in the Roberts Mountains Formation of central Nevada. University of California Publications in Geological Sciences 111, 1-62.

KLAPPER, G. \& PHILIP, G.M. 1971. Devonian conodnt apparatuses and their vicarious skeletal elements. Lethaia 4, 429-452. DOI 10.1111/j.1502-3931.1971.tb01865.x

KŘí̌, J. 1999. Silurian and lowermost Devonian bivalves of bohemian type from the Carnic Alps. Abhandlungen der Geologisches Bundesanstalt 56(1), 259-316.

LANE, H.R. \& ORMISTON, A.E. 1979. Siluro-Devonian biostratigraphy of the Salmontrout River area, east-central Alaska. Geologica et Palaeontologica 13, 39-96.

LINK, A.G. \& DRUCE, E.C. 1972. Ludlowian and Gennidian 
conodnt stratigraphy of the Yass basin, New South Wales. Bulletin of Australian Boureau of Mineral Resources, Geology and Geophysics 134, 1-136.

Mabillard, J.E. \& AldRIDGE, R.J. 1983. Conodonts from the Coralliferous Group (Silurian) of Marloes Bay, South-West Dyfed, Wales. Geologica et Palaeontologica 17, 49-43.

MANZONI, M. 1965. Faune a conodonti del Siluriano e Devoniano delle Alpi Carniche. Giornale di Geologia 2(33), 179-200.

MiLlER, C.G. \& ALDRIGE, R.J. 1993. The taxonomy and apparatus of the Silurian distomodontid conodont Coryssognathus Link \& Druce, 1972. Journal of Micropalaeontology 12(2), 241-255.

MÜLLER, K.J. \& MÜLLER, E.M. 1957. Early Upper Devonian (Indipendence) Conodonts from Iowa, part I. Journal of Paleontology 31(6), 1069-1108.

MuRPHY, M.A. \& MATTI, J.C. 1982. Lower Devonian conodonts (hesperius-kindlei zones), central Nevada. University of California Publications in Geological Sciences 123, 1-83.

MurPhy, M.A., VALENZUElA-Ríos, J.I. \& CARLS, P. 2004. On Classification of Pridoli (Silurian)-Lochkovian (Devonian) Spathognathodontidae (Conodonts). University of California, Riverside Campus Museum Contribution 6, 1-25.

PANDER, C.H. 1856. Monographie der fossilen Fische des Silurischen Systems der Russisch-Baltischen Gouvernments. 83 pp. Petersburg.

RHODES, F.H.T. 1953. Some British Lower Palaeozoic conodont faunas. Philosophy Transactions of the Royal Society of London, Series B 237, 261-334. DOI 10.1098/rstb.1953.0005

SCHÖNLAUB, H.P. 1980 Carnic Alps. Field Trip A, 5-57. In SCHÖNLAUB, H.P. (ed.) Second European Conodont Sympo- sium, ECOS II, Guidebook, Abstracts. Abhandlungen der Geologisches Bundesanstalt 35.

Serpagli, E., Corradini, C. \& Ferretti, A. 1998. Conodonts from a Ludlow-Pridoli section near the Silius Village, 104-111. In SerPagli, E. (ed.) Sardinia Field-trip Guidebook, ECOS VII. Giornale di Geologia 60, Special Issue.

SERPAGLI, E., CORRADINI, C. \& OLIVIERI, R., 1997. Occurrence and range of the Silurian conodont Coryssognathus dubius (Rhodes 1953) in southern Sardinia. Bollettino della Società Paleontologica Italiana 35(3), 239-243.

SWEET, W.C. 1988. The Conodonta: morphology, taxonomy, paleoecology, and evolutionary history of a long-extinct animal phylum. Oxford Monographs on Geology and Geophysics 10. 212 pp. Clarendon Press, New York.

ThOMAS, L.A. 1949. Devonian-Mississippian Formations of southeast Iowa. Bulletin of the Geological Society of America 60, 403-438. DOI 10.1130/0016-7606(1949)60[403:DFOSI]2.0.CO;2

VIIRA, V. 1999. Late Silurian conodont biostratigraphy in the northern East Baltic. Bolletino della Società Paleontologica Italiana 37, 299-310.

WALLISER, O. 1964. Conodonten des Silurs. Abhandlungen des Hessischen Landesamtes für Bodenforschung zu Wiesbaden 41, 1-106.

ZIEGLER, W. 1960. Conodonten aus dem rheinischen Unterdevon (Gedinnium) des Remscheider Sattels (Rheinisches Schiefergebirge). Palaeontologische Zeitschrift 34(2), 169-200.

ZUCCHINI, R. 1998. Miniere e mineralizzazioni della Provincia di Udine. Museo Friulano di Storia Naturale, Pubblicazione 43, $1-148$. 